\title{
(a) $\mathrm{W}$
}

www.ehs-ss.pl

\section{Nina Sungurova \\ Nataliya Karabuschenko}

\section{Psychological Features of the Interaction of Students in Information Educational Space}

Variety of present-day use of information and computer technologies in practice of a higher educational institution is caused by their different mission and opportunities in the solution of educational tasks. Information and computer technologies in training conduct to changes of the contents, methods, receptions and means of educational activity.

The information environment of modern educational process includes educational portals of the Internet, specialized sites, textbooks with multimedia maintenances, electronic textbooks and grants, electronic educational and methodical complexes, computer laboratory practical works, control testing sets, training computer programs, educational video movies, audio recordings. As an electronic resource information databases that includes funds of the main educational and methodical literature, periodicals, scientific literature are applied in educational process.

Network interaction, communication of virtual reality technologies with the Internet opportunities form the basis of the new educational 
spaces and environments of higher educational institutions and define openness of modern education. Virtual design in the form of visual and sound representations, simulation feelings, interactivity allow to realize educational projects of essentially new type [4].

Application of information technologies largely defines dynamics and a structure of educational and professional activity. Information technologies can be considered as special qualitatively new means of the activity, causing profound changes of this activity [12]. Application of information technologies in educational process strengthens a positive motivation of training, stirs up informative activity that allows to attract bigger quantity of a didactic material, to give classes at high emotional and aesthetic level. High extent of differentiation of training is reached, there is an additional possibility of an individual approach. Possibility of independent activity extends; skills of research work and receiving access to various information systems and improvement of learning efficiency quality are formed. Interaction with informational technologies change and involve indicative and operational-technical components of activity, transform spatial and temporary borders, form the motivational system including informative, communicative, social and standard and creative motives. As a context of activity of the subject the information and computer environment become a new source of the mental changes leading to the development which are formed in personal, cognitive, operational fields of activity.

Modern information and communication technologies allow to combine long-term storage with instant delivery of the partner or a situation (more precisely, "phantom") to another partner in communication, creating, thus, potentially inexhaustible opportunities for different re-mediations in communicative situations and changes in character of communicative events both in real time and in a mode of the delayed communication. Use of these technologies generated the whole scale of new receptions of emotional conditions transfer, including non-conventional use of symbols, diacritical badges, pictures, etc., in other words, created elements of new reality in the mediated interaction [5], [15].

The sociocultural environment formed in information educational space, and also technical capabilities of the communication mediated by a network, create conditions of variability of self-presentation of the personality [8].

Communicating in virtual educational space participants can accept new social roles. Thus the form of educational interaction can directly be 
broadcast from real life, can partially change, and can be generated in the form of a new point of view and unusual from the point of view of the developed habits and traditions of a form.

All participants of network educational interaction are active and as independent units are unpredictable. Sites, autobiographies, opinions, own publications, spontaneous discussions, forums and conferences is an opportunity to tell and be heard: differentiation of roles "communicator""recipient", status distinction are erased, becomes conditional. In virtual space the interrelation of participants of communicative process becomes not bilateral and unidirectional, and multilateral. It is a question of formation of the person's new sphere of existence of the personality "public subjectivity" which is realized in numerous options of "virtual identity" and becomes addition and way of development of the personality [8], [11], [13], [14].

Openness and branching of a network situation give the chance of simultaneous finding of the subject in different communicative structures, increase its ability to imitation, transformation, a social mimicry [17].

At the same time it isn't necessary to overestimate possibilities of information technologies. The Internet only in a certain degree allows to model interpersonal communication of teacher and pupil which essence the relations of mentoring make, cooperation and supports, nonverbal components of human communication.

Information technologies create essentially new opportunities for the organization of educational process, promote formation of special information environment in educational institution, intensify communicative communications of subjects of educational process, supplement direct communication by the mediated interaction by means of the Internet [1], [9], [10].

Virtual networks help to create the personalized environment of training, self-training and joint activity. In its turn it can provide not only different types of activity on the Internet, but also manifestation of various personal qualities of its users, creating preconditions for a communication intensification at a personal level that becomes both addition and way of development of the personality.

Internet features and communication mediated by it helps to show personal qualities of the user: existence of an appropriate level of motivation, various installations, creative activity. It creates exclusive opportunities for each user to form his or her own position. Thus there are various ways to publicity manifestation, self-expression, self- 
manifestations and identity, there are conditions for any sort of designing that in reality can cause the need to design social relations and own image of "I" [8], [14].

Considering specifics the Internet technologies not only as a way of education, but also as a unique opportunity for development of communicative abilities, an important feature comes to light. It becomes real to create not only of communicative situations, but also to create development, to plan and implement such educational tasks which can answer as much as possible to the personal, educational and professional purpose of students.

Thus, on the one hand, it is possible to use quickly and easily the most different information in the Internet environment, to increase informative activity of the trainee, to realize individual educational trajectories. But on the other hand, the detailed psychological analysis of "Internet addiction disorder", characterized by duration of use, high degree of an involvement, low level of control over the actions is necessary. This phenomenon leads to family problems, social isolation as psychological consequences [2], [16], [17].

Intensive introduction of information technologies in education comprises not only the huge developing potential, but also a number of the negative moments [6].

In a number of software products, there is a mismatch of the on-screen media (its structure, logical construction, aesthetic design, the feed rate of educational material and so on.) to individual abilities and age features of students.

Information and computer environments of training give easy access to information, develop erudition, but don't promote independent development of new knowledge. The side between knowledge and information is more and more erased.

In traditional system of training it is the system and conjunctive thinking that develop. The computer program works by the principle of a choice of option among available alternatives. The emphasis is placed on formal subject knowledge out of a context and a situation.

Educational interaction within realized information and computer activity during which there is an intellectual and emotional and strongwilled development of students has no due development either.

Information and computer interaction leans generally on the visual canal of perception of an information that deprives of opportunity to develop acoustical and kinesthetic channels that's how the individual 
approach in training is realized.

Serious problem is that the saturation of the software leads to difficulties with the letter, perception, understanding of the text, to difficulties with the speech [6].

We call attention to another aspect of the psychological consequences associated with the phenomenon of "ekzution", in other words an exception, dying formed, but unnecessary abilities, skills, types and forms of activity. The literature contains already data about the expiring arithmetic skills, oral reading skills.

The use of information and computer technology education should be viewed in the context of the phenomenon of synergy pedagogical influence. It is understood as the result of mutual actions of its constituent factors, besides; the cumulative effect exceeds the action exerted by each of these factors separately.

We present the results of empirical studies of students' person in the context of network activity. Students of Moscow universities took part in research. The sample size was 270 people.

Psychodiagnostic complex of research included the following methods: questionnaire of behavior on the Internet" (AE Zhichkina); questionnaire of attitudes towards the Internet (E. Hubenko) questionnaire "I'm in Internet communication" (I. Shevchenko) [3], [7], [12].

The main areas of using the Internet by participants of study: search activity, communicative activity and creative and utilitarian activities. The percentage is shown in figure 1.

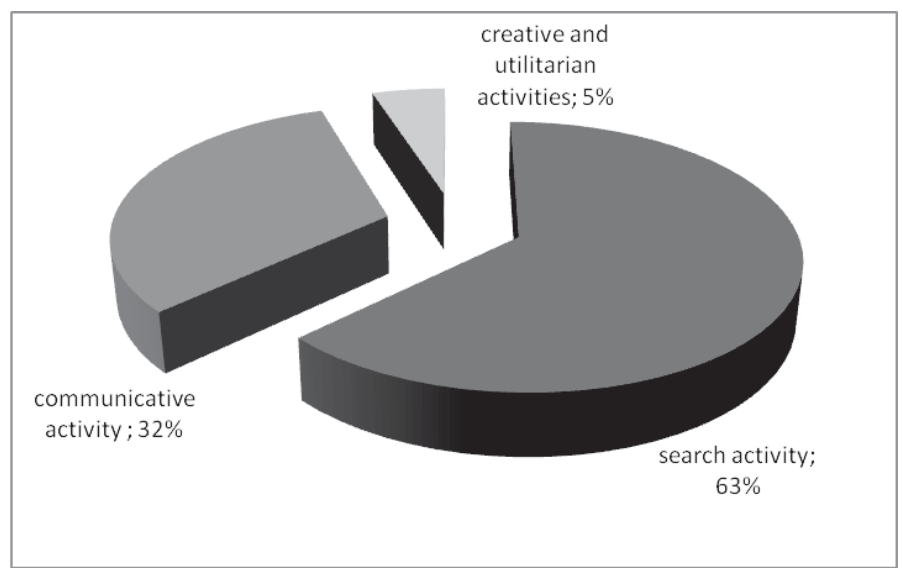

Fig.1. Areas of use of the Internet 
$63 \%$ of students use the Internet to search for information related to training, work or hobby; to download various programs; to find people in the region of interest. $32 \%$ of the students are directed to communication activities. About $5 \%$ of respondents have demonstrated on organizational and creative activities (website development, project support).

Three types of network activity students were identified by the nature of Internet interactions. "Activity in the perception of alternatives» that is characterized by respondents with expressed desire to search for their identity and the desire to live through a new experience that is impossible to feel in real life. This is manifested in the interest to read other people's messages, view websites, portals of different content, to express evaluative attitude to the photo or video material. "Activity in Action» is typical for people with weak social and role-playing component. In the network, they are often the first to get to know; offer their topic; they are usually online to present their personal status. «Internet addiction» is associated with the perception of the Internet as an environment capable of giving emotional support to cope with grief and loneliness, provide an opportunity self-expression and self-presentation. These are people with hypersensitivity to social constraints.

The ratio of the average tendencies attitude of students on the attitude to the Internet distributed as follows: «social comfort» (29.03), «reduction of self control» (25.8), «diversion» (24.3), «loneliness / depression» (14.5). Mathematical processing using the Friedman test has identified statistically significant differences between the scales $(\chi \mathrm{r} 2=111.77 ; \mathrm{p}=0)$.

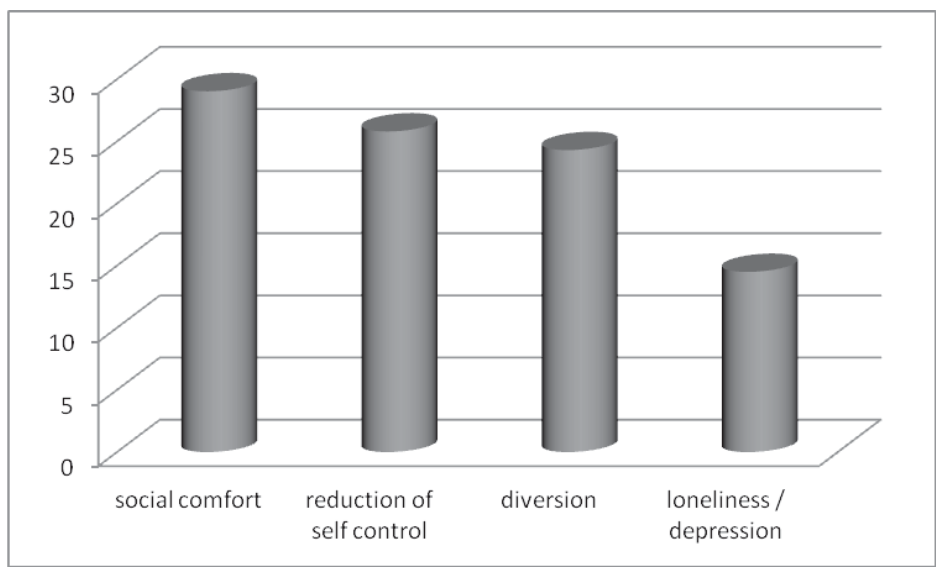

Fig. 2 «Attitude of students on the relation to the Internet» 


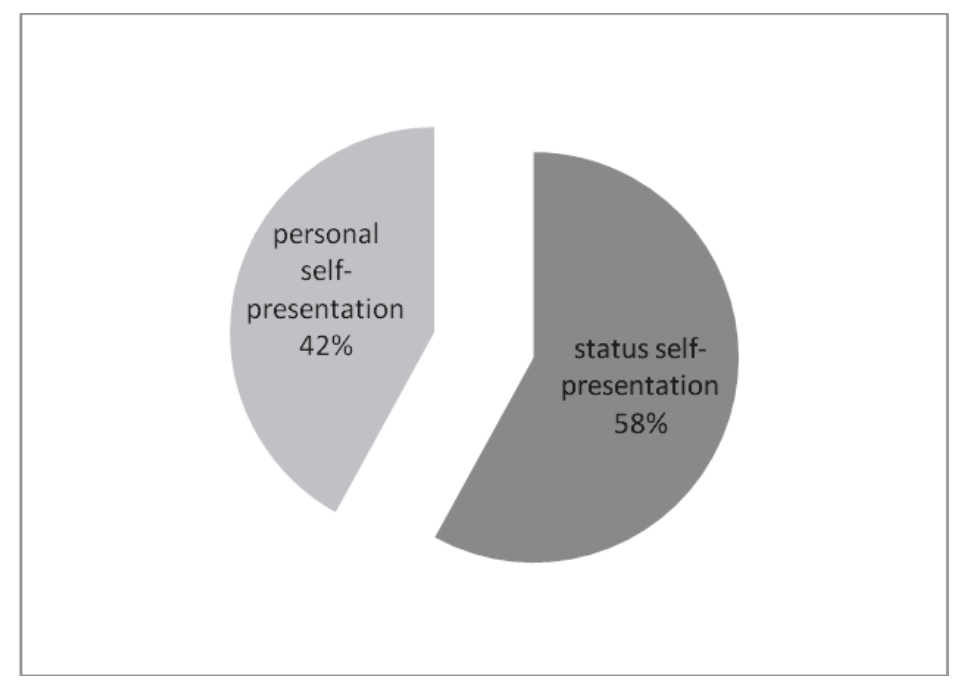

Fig. 3. «Image»I «in Internet communication»

The Internet as means of communication leads to a variety ways of students' self-presentation. The virtual space provides comfort, allows to realize the need for social support, somewhat gives a sense of tranquility and security. It is shown that the more students use the Internet as a distraction from the real work, the more they have difficulties in the organization of their activities and in the management of real communication in their environment. The high level of moral variability, observance of moral rules of behavior in the Internet environment leads to a comfortable social interaction in virtual space.

«Status self-presentation» and "personal self-presentation» are also indicated in the study of personality expression features in network resources.

Expression of different social roles, use and variation of their personal and social status, personal style is typical for the respondents" "I" image in "I'm in Internet communication". Students emphasize their personal status, vary with their social position giving the impression of themselves in the Internet communication. There are cases of representations of the other sex, another age or profession. Students tend to give special value style, content of communication, depending on the role they occupy in the dialogue. A high level of moral variability, observance of ethical rules of behavior in the Internet environment leads to a comfortable social interaction in virtual space. 
Students master the information and computing environments, which can lead not only to the positive side, from the perspective of student psychology and psychology of learning, but also cause negative personality changes, unwanted transformation of educational activity. But since the informatization of education becomes a huge scale, it requires serious study of the psychological consequences of this process.

\section{References:}

1. Graff M. Individual Differences in Hypertext Browsing Strategies // Behaviour \& Information Technology. 2005. Vol. 24. P. 93-99

2. Holland N. The Internet Regression // www.rider.edu /users/suler /psycyber / holland.html

3. Hubenko. E. Internet and the Problem of Psychic Health. - M., 2003.

4. Modern Information Technologies / Under. N.V. Bardovsky. - M.: KNORUS, 2010.

5. Noy C. CD-Mômes. L'enfant et les tehnologies educatives. - Paris. France. - 2006.

6. Shadrikov V.D., Shemet I.S. Information Technologies in Education: Plus and Minus // Higher Education in Russia. № 11, 2009, p. 61-63.

7. Shevchenko A. S. The Study Of Self Presentation of Personality in Internet Communication.- M., 2003.

8. Sungurova N. L. The Individually - Personal Features of Students in Information and Psychological Space. - Moscow, Peoples' Friendship University of Russia, 2014.

9. Sungurova N. L. Psychological Attitude of Students to Information and Computer Learning Environment // Bulletin of the Russian People's Friendship University. Series: Psychology and Pedagogy. 2013. № 3. P. 116-122.

10. Sungurova N.L. Psychological Effects of Mastering Learners Computer Information and Educational Environment // Bulletin of the Moscow State Academy of Business Administration. Series: The philosophical, social and natural sciences. № 5 (17). 2012. P/ 135-144.

11. Temple L., Lips H.M. Gender Differences in Internet Usage and Task Preferences // Behavior \& Information Technology. 2000. Vol. 19. P. 283-295.

12. Tikhomirov O.K. The Information Age and the Theory L.S. Vygotsky // Journal of Psychology, 1993, t.14, № 1, pp. 114-119.

13. Turkle Sh. Constructions and Reconstructions of the Self in Virtual Reality / Massachusetts Institute of Technology. Idenity workshop. 1997// http://www. pscw.uva.nl/sociosite/psyberspace.html

14. Turkle Sh. The Second Self: Computers and Human Spirit. N.Y. Simon and Schuster, 1984.

15. Voiskunsky A. E. Humanitarian Internet // Humanitarian research on the Internet / Under A.E. Voiskunsky. M .: Mozhaisk Terra, 2000, pp 3-

16. Young K.S. Psychology of Computer Use: XL. Addictive Use of the Internet: A Case that Breaks the Stereotype // Psychological Reports. 1996. Vol. 79. P. 899-902.

17. Young, Kimberly S. Caught in the Net. How to Recognize the Signs of Internet 
Addiction And a Winning Strategy for Recovery, 1998// http://www.netaddiction. com/infidelity_online.htm

18. Zhichkina A.E. Interrelation of Identity and Behavior on the Internet Users of Youthful Age. - M., 2001.

\section{Transliteration of references:}

1. Graff M. Individual Differences in Hypertext Browsing Strategies // Behaviour \& Information Technology. 2005. Vol. 24. P. 93-99

2. Gubenko. Je. Internet i problema psihicheskogo zdorov'ja. - M., 2003.

3. Holland N. The Internet Regression // www.rider.edu /users/suler /psycyber / holland.html

4. Noy C. CD-Mômes. L'enfant et les tehnologies educatives. - Paris. France. - 2006.

5. Shadrikov V.D., Shemet I.S. Informacionnye tehnologii v obrazovanii: pljusy $\mathrm{i}$ minusy// Vysshee obrazovanie v Rossii. 2009. №11.S.61-63.

6. Shevchenko A.S. Issledovanie samoprezentacii lichnosti v Internet-obshhenii.M., 2003

7. Sovremennye informacionnye tehnologii / kol.avtorov; pod red. N.V. Bordovskoj. - M.: KNORUS, 2010.- 432s.

8. Sungurova N.L. Individual'no-lichnostnye osobennosti studentov V informacionno-psihologicheskom prostranstve. - Moskva, RUDN, 2014.

9. Sungurova N.L. Psihologicheskie posledstvija osvoenija obuchajushhimisja informacionno-komp'juternoj obrazovatel'noj sredy // Vestnik Moskovskoj gosudarstvennoj akademii delovogo administrirovanija. Serija "Filosofskie, social'nye i estestvennye nauki". - № 5 (17)/2012.

10. Sungurova N.L. Psihologicheskoe otnoshenie studentov $\mathrm{k}$ informacionnokomp'juternym obuchajushhim sredam // Vestnik Rossijskogo universiteta druzhby narodov. Serija: Psihologija i pedagogika. 2013. № 3. S. 116-122.

11. Temple L., Lips H.M. Gender Differences in Internet Usage and Task Preferences // Behavior \& Information Technology. 2000. Vol. 19. P. 283-295.

12. Tihomirov O.K. Informacionnyj vek i teorija L.S. Vygotskogo// Psihologicheskij zhurnal. 1993. t.14. № 1. S. 114-119.

13. Turkle Sh. Constructions and Reconstructions of the Self in Virtual Reality / Massachusetts Institute of Technology. Idenity workshop. 1997// http://www. pscw.uva.nl/sociosite/psyberspace.html

14. Turkle Sh. The Second Self: Computers and Human Spirit. N.Y. Simon and Schuster, 1984.

15. Vojskunskij A.E. Gumanitarnyj Internet// Gumanitarnye issledovanija v Internete / Pod red. A.E. Vojskunskogo. M.: Mozhajsk-Terra, 2000. p. 3-10.

16. Young K.S. Psychology of Computer Use: XL. Addictive Use of the Internet: A Case that Breaks the Stereotype // Psychological Reports. 1996. Vol. 79. P. 899-902.

17. Young, Kimberly S. Caught in the Net. How to Recognize the Signs of Internet Addiction And a Winning Strategy for Recovery, 1998// http://www.netaddiction. com/infidelity_online.htm

18. Zhichkina A.E. Vzaimosvjaz' identichnosti i povedenija v Internete pol'zovatelej junosheskogo vozrasta. - M., 2001. 
The Authors

Nina Lvovna Sungurova, PhD, Associate Professor, Psychology and Pedagogics Department, Peoples' Friendship University of Russia, Moscow, Russia e-mail:sungurovanl@mail.ru

Nataliya Borisovna Karabuschenko, Doctor of psychological sciences, professor, Chair of Psychology and Pedagogics Department, Peoples' Friendship University of Russia, Moscow, Russia e-mail:n_karabushenko@inbox.ru

НІНА СУНГУРОВА, НАТАЛІЯ КАРАБУЩЕНКО. Психодогічні особдивості взаємодії студентів в інформаційному освітньому просторі. У статті аналізуеться проблема психологічних особливостей взаємодї студентів в інформаційній освітньому середовищі. Інформаційні технології розглядаються як особливе якісно новий засіб опосередкування навчальної діяльності. Автори виділяють позитивні і негативні сторони реалізації процесу навчання з використанням інформаційно-комп'ютерних технологій. Мета емпіричного дослідження виявити психологічні особливості варіативносmі поведінки у віртуальному просторі, установок особистості по відношенню до Інтернету.

Ключові слова: психологічні наслідки, інформаційно комп'ютерна освітне середовище, взаємодія, Інтернет-навчання, установки по відношенню до Інтернет.

NINA SUNGUROVA, NATALIYA KARABUSCHENKO. Psychologiczne cechy interakcji z uczniami w przestrzeni informacyjnej edukacyjnej. W artykule analizuje się problem psychologicznych właściwości współdziałania studentów w informacyjnym oświatowym środowisku. Informacyjne technologie rozpatruja sie jak szczególne jest jakościowe nowy środek upośredniania ćwiczebnej działalności. Autorzy wydzielaja pozytywne i negatywne strony realizacji procesu nauczania z użyciem informacyjny-komputerowych technologii. Cel empirycznego badania ujaw- 
nić psychologiczne właściwości wariantowej zachowania w wirtualnym obszarze, ustawień jaźni w stosunku do Internetu.

Stowa kluczowe: psychologiczne skutki, informacyjne komputerowe oświatowe środowisko, wspótdziałanie, Internet-nauczanie, ustawienia w stosunku do Internetu.

НИНА СУНГУРОВА, НАТАДИЯ КАРАБУЩЕНКО. ПсИходогические особенности взаємодействия студентов в информационном образовательном пространстве. В статье анализируется проблема психологических особенностей взаимодействия студентов в информациинной образовательной среде. Информационные технологии рассматриваются как особое качественно новое средство опосредствования учебной деятельности. Авторы выделяют положительные и отрицательные стороны реализации процесса обучения с использованием информациионо-компьютерных технологий. Цель әмпирического исследования выявить психологические особенности вариативности поведения в виртуальном пространстве, установок личности по отношению к Интернету.

Ключевые слова: психологческие последствия, информационно- компьютерная образовательная среда, взаимодействие, Интернет-обучение, установки по отнотению $к$ Интернет.

NINA LVOVNA SUNGUROVA, NATALIYA BORISOVNA KARABUSCHENKO. Psychological features of the interaction of students in information educational space. The problem of psychological features of the interaction between students in the information educational environment is analyzed in this article. Information technologies are considered as special qualitatively new means of a mediation of educational activity. Authors allocate positive and negative sides of realization of the learning process which uses information computer technologies. Information technologies create essentially new opportunities for the organization of educational process, promote the formation of special information environment in an educational institution, intensify communicative communications of subjects of the educational process, supplement direct communication by the mediated interaction by means of the Internet. The purpose of the empirical study reveals psychological characteristics of student personality in network interaction, the variability of behavior in the virtual space, attitude toward the Internet. Key words: Psychological consequences, Information computer educational environment, Interaction, Internet training, attitude toward The Internet. 